\title{
Making Women in Jazz Visible: Negotiating Discourses of Unity and Diversity in Sweden and the US
}

\author{
Cecilia Björck \\ University of Gothenburg \\ cecilia.bjorck@gu.se
}

\author{
Åsa Bergman \\ University of Gothenburg \\ asa.bergman@gu.se
}

\begin{abstract}
The aim of this article is to examine responses to a project that aspires to further genderequal jazz scenes in Sweden and the US. The project brought together actors at various levels of the industry: cultural agencies, commercial organizers, activists, and artists. Our analysis - with special focus on resistance voiced - is based on observations, interviews with organizers, and a documentary about the project. The project's central ambition was to make women in jazz visible in order to change a structural imbalance where men still take up most of the space on stage. This ambition was, however, complicated as different actors resisted a female-male binary, and thus the very idea of "women in jazz". The resistance was played out through gender equality discourses of either unity or diversity, varying in relation to national context and generation. The article also discusses visibility as a central but also problematic aspect for gender equality efforts in music.
\end{abstract}

KEYWORDS: music and gender equality, women in jazz, visibility, resistance, ethnography, discourse

\section{Introduction: Background, aim and context}

Previous research has demonstrated the difficulties faced by women wishing to participate in a number of male-dominated music genres (for example Bayton 1998; Citron 2000[1993]; Leonard 2007). Jazz is no exception, commonly being "thought of and historicized as a 'man's world,' sometimes decorated by 'girl singers'" 
(Tucker 2016: 256). Various initiatives have been launched to counteract and compensate for such dominance (Björck 2011). The present article examines an initiative to further gender-equal jazz scenes in Sweden and the US, bringing together actors at various levels of the industry: cultural agencies, commercial organizers, artists, activists, and students. The project was owned by a Swedish regional cultural administration and formed an international cultural exchange in 2015 between a women-in-jazz festival in Sweden and one in the US. The aim of the article is to examine how various actors in the jazz industry responded to the project, with special focus on resistance voiced and how this varied between Swedish and US participants.

Sweden and the US share some relevant aspects. In both countries, grass root efforts have been significant for countering the effects of male-dominated and sometimes misogynist music scenes, often by creating alternative women- and girlsonly spaces offering opportunities to network, to perform, and to develop technical and artistic skills in a supportive environment (Björck 2013). In the 1970s US, this included the start-up of women's music festivals, women's music organizations, and alternative record labels run by women. Kernodle (2014: 52) points out that these initiatives often excluded black women musicians, who as a result "began to create their own collectives and support groups". A number of all-women bands also developed during this time in both US and Sweden, often inspired by punk culture (Ganetz 1998). Within US indie music in the early 1990s, the riot grrrl movement emerged where the all-girl band was viewed as a space for safety and resistance (Leonard 2007). In both countries, the early 2000s saw the first Ladyfest festivals and rock camps for girls, foregrounding rock as a way to empowerment and self-esteem (Dougher and Keenan 2012). In jazz, international networks and programs for women were formed during the 1990s, such as International Women in Jazz (established in 1995) and the Sisters in Jazz program (started in 1997 as part of the International Association for Jazz Education).

Today, gender equality efforts in music apply to a broad range of genres and musical activities, some of which also welcome people with transgender and nonbinary identities. In addition to rock camps, there are a number of jazz camps for girls and for adult women in both Sweden and the US. Recently, activist networks have brought attention to the great dominance of male artists showcased at music festivals, and demands to stop sexism and sexual harassment following the global social media campaign \#MeToo has shaken various professional sectors during the fall of 2017 in both Sweden and the US, including the music industry.

Despite a similar history of girl- and women-centered initiatives critiquing gender inequalities in the music industry, there are also differences between US and Sweden. A comparison of women's movements in Western democracies (Mazur et al. 2016) shows the US exhibits high levels of mobilization - activism through informal networks, protests, and policy campaigns - while Sweden instead exhibits a high level of institutionalization, being "the only country that shows consistently high presence of women's movement actors especially in legislatures, higher civil service, and political party leadership" (2016: 662). There are additional differences in cultural policy. To our knowledge, the US has no national-level strategy for tackling gender inequalities in music, and programs with such aims are funded primarily by volunteer work and by private donations. The US thereby appears similar to how de Boise (2017: 1) describes the UK: an "arm's length" approach to cultural policy as well as gender equality, encouraging market-oriented solutions. This means that grass root initiatives are required for change to happen. In contrast, Sweden applies what de Boise (2017: 1) calls a "cultural democracy" approach, a tradition of state intervention through national and local gender 
equality policies. ${ }^{1}$ Two national reports commissioned by the Swedish government (Sweden 2006; Statens kulturråd 2009) showed jazz music to be the least genderequal performing arts sector in terms of resources distributed. The reports also pointed out that instrumental positions remain strongly sex-stereotyped in jazz, in contrast to so-called art music where women have gradually entered traditionally male instrumentalist positions (cf. Annfelt 2003). Furthermore, these reports stated that the dominance of informal networks in jazz appeared to reproduce such stereotypes. As a consequence, the Swedish Arts Council took on an equality strategy in 2010, and a new Swedish Agency, Musikverket, was assigned a special mission by the government to support projects working for greater gender equality in music in 2011-2014.

The ambition to promote visibility for women in jazz unavoidably connects to issues of marketing and sponsorship, as well as cultural policy. We believe the similarities and differences between Sweden and the US accounted for here make a collaborative project, such as the one under study, an interesting site for analyzing meaning-making and resistance in gender equality work in jazz.

\section{Previous research}

Previous research relevant for this study includes studies on gender and jazz, but also on gender-equity work in music more broadly. To begin with, research has demonstrated how women's marginalization in jazz relates to the genre's masculine connotations (Caudwell 2012; Heble and Siddall 2000; Smith 2004; Suzuki 2013; Tucker 2004; Wehr 2016). According to Heble and Siddall (2000), "jazz has been discursively constructed as a male preserve" (146) where "[i]mplicit in the term jazz musician (...) is the word male" (156, original emphasis). Annfelt (2003) describes jazz as a hegemonic masculine discourse, thereby inherently heterosexual. Masculine dominance is furthermore described to be reinforced through conventions of musical practice, where "[g]ender and sexuality, in relation to men, masculinity, and virility, all play their part in defining normative productions of musical style and sound" (Caudwell 2012: 398). Jamming and improvisational practices, often considered a model of democratic process, are paradoxically pointed out to reproduce male entitlement to jazz (Caudwell 2012; Smith 2004) through ideals closely connected to masculinity, such as rebelliousness and risktaking (Annfelt 2003). These practices can also be considered elitist because they establish a division between audience and musician (Gooley 2011) - a division which the British Feminist Improvising Group (FIG, formed in 1977) worked to break down by constructing improvisation as something "anyone can do" (Smith 2004: 236). Using FIG as an example, Smith argues that free jazz improvisation can serve as an area for articulating critique through humour and parody.

Issues related to instrumentalist and vocalist positions are also recurring in research on gender and jazz. The traditional division of labour in jazz and in jazz education, where singers are likely to be women while instrumentalists (other than pianists) are likely to be men (Annfelt 2003), is similar to other popular music genres (Green 1997). While women jazz singers are on the one hand rendered highly visible by the front stage position, they have on the other hand been excluded from jazz research and canon and given lower status than instrumentalists by association between singer, commodification and sexuality (Istvandity 2016; Pelligrinelli 2008). As for instrumentalist positions, the exclusion of women appears particularly strong for saxophones, trumpets, and trombones - instruments strongly associated with male heterosexuality and virility (Caudwell 2012). In addition, the instrumental 
jazz scene is considered as a site where gender and race merge in complex dialogues which are, among other things, linked to ideas about authenticity (see Monson 1995; Suzuki 2013).

While some studies focus on the benefits of women-in-jazz efforts (Denson 2014), others have discussed more problematic aspects. Brewer's (2017) account of the first Women in Jazz Festival in the US includes controversy between (among others) those who accepted the inclusion of male sidemen and those who did not. Heble and Siddall (2001) describe tensions around a women-in-jazz theme at a jazz festival in Canada, where sponsors tried to avoid being associated with feminism, and some featured women artists expressed concerns about "wanting to be seen as musicians period, not ghettoized as women performing artists" (163, original emphasis). In retrospect, Heble and Siddall recognize the program as "both problematic and promising" (164) - problematic because such a theme "runs the risk of invoking expectations and possibly stereotypes about female performers" (161); promising because it could be seen as a form of political activism taking small steps to change public perceptions on the role of women in jazz, and to enable increased access to performance opportunities for women. Tucker (2004: 246) further problematizes the "sometimes voluntary, sometimes reluctant, set of imagined jazz communities that we may awkwardly call 'women-in-jazz'". She wants to separate the term

from the players it seeks to contain, in order to suggest that the power of women-in-jazz is that it marks a place just on the edge of jazz where women have persisted as cultural producers despite differences among them, and despite a centurylong gendered history bent on excluding them. (2004: 246)

Similar tensions around female/feminine labels have been raised in other popular music genres. Interestingly, resistance against such labels is sometimes based on feminist critique (Keenan 2008), and sometimes on refusal to be coded as feminist (Coates 1997). The nature of feminist approaches adopted by women- or girlcentred initiatives in music overall appears as a balancing act. In a Swedish context, Björck (2011) found a central argument voiced by such initiatives was that young women need to "claim space" in order to participate in popular music, an idea found to slide between a collective feminist social justice discourse, and an individualistic neoliberal market-oriented discourse. The participants in Björck's study furthermore discussed how girl-centred programs risk marking girls as special, Other, and in need of help. In a US context, Giffort (2011) describes how organizers of Girls Rock! Midwest (GR!M) responded to the dilemma of working in post- and anti-feminist surroundings by employing a strategy of "implicit feminism", that is to say, toning down feminist identity, not labelling feminist ideas as such, and emphasizing more socially acceptable angles of their efforts to those outside of the organization.

Finally, some previous studies focus on social and psychological barriers which might explain women's underrepresentation in jazz and how these barriers can be countered. Wehr (2016: 482) finds that "in jazz, a female is often the only one, and potentially placed in a token role that induces stereotype threat that inhibits the experiencing of the multiple, small successes in jazz that build self-efficacy". In terms of formal music learning, McKeage (2014[2002]) interviewed female undergraduate music majors who related their own withdrawal from college jazz bands to pressure from teachers to study the classical tradition, negative social environments in jazz ensembles, and disconnections between jazz participation and career aspirations. 
Most of the previous studies we found relevant to gender equality work in jazz are situated in a North American context. Methodologically, many of them draw on small-size, single-form empirical data. Comparative approaches and ethnographic studies in contrast appear to be very scarce, indicating that the present study can make a contribution to this field.

\section{Theoretical framework}

To understand dilemmas characterizing gender equality work in music, we deploy a poststructural line of thinking where gender, knowledge and subjectivity are viewed as socially constructed, constantly negotiated and pervaded by discourse. Following Foucault (1972), a discourse is a way of speaking about something, constituting a network of meaning which provides access to certain ways of understanding the world. How we speak of jazz music and gender equality shapes how we might understand these concepts, and, by extension, what actions will appear favourable. Discourses are here not considered to be individual properties, nor do we seek individual consistency; instead, we align with a post-structural interest in the discontinuities, slidings, dilemmas and gaps made visible through discourse.

Power and resistance are closely connected to discourse for Foucault. As pointed out by Scott (1988: 35), Foucault suggests that "the elaboration of meaning involves conflict and power, that meanings are locally contested within discursive 'fields of force $^{\prime \prime \prime}$, and that claims to knowledge in these force fields are embodied in writing, in disciplinary and professional organizations, institutions and social relationships. Viewing both freedom and resistance as necessary and immanent to power relations, Foucault (1982: 780) suggests that "in order to understand what power relations are about, perhaps we should investigate the forms of resistance and attempts made to dissociate these relations". Following this suggestion, the present study could help us understand more about power relations in the jazz field by examining how meanings of gender equality work in jazz are elaborated and contested in a specific project. Gender equality efforts can themselves be seen as forms of resistance, aiming to change current conditions, but as we have seen from previous research, such efforts may also in turn generate other forms of (internal) resistance.

A concept central to Foucault's (1977) notion of power, useful for discussing visibility, is that of gaze. This refers to how the act of looking may exercise control by establishing a subject-object relationship. Feminist researchers have argued that ways in which women are visually inspected, and also learn to inspect themselves, are rooted in a patriarchal value system. Young (1989), for example, uses the concept to discuss how learning how to be a woman involves a bodily tension between being an acting subject and an object to be mastered.

Although women's movements are not to be entirely conflated with feminist movements, ${ }^{2}$ feminist theory has nevertheless influenced struggles for women's rights. According to Alcoff (1988: 405), the concept of woman is a problem of "primary significance" for feminist theorists; a central concept for self-definition, yet "crowded with the over-determinations of male supremacy, invoking in every formulation the limit, contrasting Other, or mediated self-reflection of a culture built on the control of females". From the 1990s, scholars have combined poststructuralist insights with a broad range of theoretical perspectives including deconstruction, queer theory and postcolonial critique, whereby the dimension of gender is seen to intersect with other power relations pertaining to hierarchies of 
race, sexuality, and so on. Following these theoretical cross-fertilizations, different feminisms can now "be viewed as representing historically contingent relationships, contesting fields of discourses, and sites of multiple subject positions" (Brah and Phoenix 2004: 82). Although the present study is mainly focused on gender, we acknowledge the concept of woman to be positioned in this intersectional complexity.

\section{Method, design and analysis}

Our material includes observations at various project events (kick-off, festivals in the US and in Sweden, and closing event), formal interviews with project organizers and informal talks with other participants during fieldwork, a documentary about the cultural exchange between US and Swedish musicians within the project, ${ }^{3}$ and a detailed project report. Material in Swedish quoted in this article has been translated into English by the authors. Media coverage and printed information about the project provided us with background material. The project was owned by a Swedish organization and several events were organised as part of this project in Sweden. Among these events, a festival (which also included a conference) formed a central site for discussion between various actors. A large part of the data was thus generated in a Swedish context. Data generated in a US context include two interviews and observations at the project's kick-off.

Our methodological approach is ethnographic, combining participant observations with interviews to produce the most multifaceted view of the project as possible (Hammersley and Atkinson 2006[1995]). In addition to first-hand experience of the events, this approach gave us access to various individual accounts about being a jazz musician and about being involved in a women-injazz project. Observations and informal conversations at events were documented through field notes and later followed up by six interviews with people in central positions in Sweden and the US (three audio recorded in-depth interviews and three shorter interviews done via email or telephone).

Following our research questions, we have identified instances in the data where individuals articulate responses to the project and its ambitions, with a special focus on resistance. Analysis has been ongoing throughout the project through a collective and dialogic process. The project owners and all informants who were formally interviewed have given their consent to participate in the study.

In sum, the design of the present study includes access to varied ethnographic data generated over more than a year, involving various participants in two countries where the women's movements have shown markedly different strengths, combined with a theoretical framework for understanding discourse, resistance and negotiation.

\section{The jazz project's structure, program and activities}

The project's stated ambitions were, in short, to encourage, support and make visible women jazz musicians and composers, and to further discussions and knowledge about how to work for a gender equal music scene. In broader terms, the project also aimed to contribute to the growth of jazz as an art form by generating knowledge and exchange, drawing in broader audiences, and stimulating regeneration of jazz musicians. In this section, we examine the project from a descriptive angle: how it was designed to perform these ambitions. 
The project - co-funded by five Swedish organizations (four of them public sector based and one industry based) - was carried out, first, by a cultural exchange during an annual women-in-jazz festival in the US, and second, by organizing a womenin-jazz festival in Sweden. A central strategy was to create national and international contacts and networks, and two new constellations - an American quintet and a Swedish sextet - were formed especially for the project to participate in performances and workshops/clinics in both the US and the Swedish festival. The two ensembles also met to compose, improvise, rehearse and perform together through a residence in Sweden.

The project had its official kick-off at the US festival, where a Swedish delegation (industry and organization representatives, scholars, and the Swedish sextet) participated in a one-day event of seminars and musical performance. About seven months later, a women-in-jazz festival was arranged in Sweden. Intended as a meeting spot, both for experiencing multifaceted musical expressions and for discussing gender and equal opportunities in the music industry, the festival invited anyone involved in the trade. Fifty-two women musicians of a broad age span performed on stage, as to challenge the often-heard claim that there are few women in jazz. The program also included a conference with an ambitious array of daytime lectures, seminars, panels and workshops performed by scholars and cultural industry representatives, including top leadership positions. Central questions concerned how to achieve a gender equal music scene, and how to apply gender equality and norm critique in organizing events.

\section{Points of resistance}

In this section, we will analyze thematically how the project's ambitions were complicated as different actors expressed resistance. We begin by examining various aspects of the most dominant theme, forming a critique against the very category 'women in jazz', after which we observe some other, less dominant themes which nevertheless raise relevant questions.

\section{Resistance against the category and label 'women in jazz'}

Discomfort with the label 'women in jazz' concerns several entangled aspects, as illustrated by the following quote from the documentary (created as part of this project). A Swedish saxophonist here talks about how she opposes gendered categorizations, says that she plays with musicians she likes regardless of their gender, and that she was quite reluctant to take part in the project because of the word 'women' in its title:

The band I am in, for instance, we never intended to be a girl band, but every review we get makes a point of mentioning this fact. Not so much the music. Sure, the music is mentioned, but they always have to point out that we are all women. But we have not defined ourselves so, I have not told them my gender identity, or what gender another band member identifies with. That's just how things have turned out when others write about us. It is that external gaze directed towards us, that defines our gender as seen from the outside. Even though it is nothing we have chosen ourselves. (dir. Norrmo 2015: 16.2017.10)

The quote indicates that the 'women' label feels uncomfortable as it singles out women, marks them as different, assumes a certain gendered identity, and draws 
attention away from music. Much of the resistance voiced in our data concerns generalizations - not all women are the same, it is argued, and similarly not all men. During a panel discussion at the Swedish festival, a vocalist emphasizes that increasing women's participation in jazz is foremost a matter of democracy, adding that greater plurality is more fun.

The resistance also concerns visual expectations following the 'women' label. In previous research, visibility is discussed as a deeply problematic aspect, since a strong focus on bodily display entails a loss of musical value for women musicians (as argued by Green 1997; Istvandity 2016; Pelligrinelli 2008, amongst others). The Swedish festival featured lectures about the stereotypical ways women are represented in media, and musicians testifying they had been asked to act more "feminine" in promotion and media images. A Swedish pianist explains at a panel discussion why she quit singing to only play the piano: when she sang, everyone would see her only as a vocalist, rather than pianist. Visibility thus goes beyond the superficial. It involves identification by being visible as something and thereby categorized, and to be seen primarily as a woman appears to be a core problem for women in jazz (cf. Alcoff 1988). The theoretical concept of gaze - interestingly enough used by the musician cited in the block quote above - might help us understand the complexity of being looked at as a movement between subjectification and objectification, where the latter seems especially problematic for groups marked as Others (cf. Björck 2011, 2013). As phrased by a Swedish saxophonist in the documentary: "What I want is for people to forget that those on stage are women" (dir. Norrmo 2015: 23.09-23.15).

Some actors argue, however, that not only women who present themselves in feminine ways are marked as Others. The US project coordinator tells us in an email interview (2017) that from her experience, such marking might also happen to "those that present themselves as being non-binary (though they may have been born genetically female)". She mentions a local example from her city where a trumpet player had performed wearing baggy pants and a baseball cap, an appearance which engendered mixed responses from the audience and a vivid debate. The project coordinator continues:

Essentially, it is my belief that the anger felt by women in jazz is rooted in being a marginalized group in this field in general. No matter what is worn, and no matter how good of a musician you are, many women are not provided with equitable opportunities strictly because they are not men. (US Project Coordinator 2017)

From this perspective, the category of women is needed to point out systematic inequalities, however diverse this group may be. In a separate email interview, the founder and director of the US festival admits that she has considered omitting the 'women' label - but for a different reason:

I have talked about starting a festival which is women-directed and womenfocused but not using 'women' in the title. I think this would be easier with federal funding which is extremely limited or unavailable for community festivals. I have to market my festival as '[Name of city] Women in Jazz' to the audience of women concert goers (...). (US Festival Founder 2017)

Paradoxically enough, then, in the Swedish context which is characterized by an institutionalized women's movement (Mazur et al. 2016), a cultural democracy approach (de Boise 2017), and public funding of projects such as the one under 
study, women jazz musicians still describe the 'women' label to cause discomfort. In the US context, lacking national-level strategy for tackling gender inequalities in music, actors instead point out that although the 'women' label might (in contrast to Sweden) be disadvantageous in terms of funding, the label is needed both to attract a (female) audience and to discuss inequalities.

\section{Sisterhood solidarity contested}

The label 'women' is also criticized for assuming a collective unity. The need for women's collectives is often brought to the fore in discussions on gender equality in the music industry, in this project as well where several musicians share stories about how important it was for them to make music and keep in touch with other women in order to survive in the industry. This importance can be understood in relation to jazz music being inherently coded as masculine (see Annfelt 2003; Heble and Siddall 2000). There are, however, instances when the idea of sisterhood solidarity is contested, complicating the project's ambition to provide networking opportunities for women musicians. The project report critically self-reflects that while the Swedish musicians taking part in the exchange felt seen through their participation in the project, not all of them felt strengthened or supported. Some of them questioned the benefit of forming a new ensemble solely for the purpose of a specific project. This comment points to the issue that musical collaborations between women cannot automatically be expected to function as supportive or encouraging. In a panel discussion at the Swedish festival, a middle-aged Swedish saxophonist rejects the idea that it is easier to communicate with women, arguing that she loves working together with male colleagues and that a person's designated sex "doesn't matter". She recounts gender identification growing up as a troublesome process, realizing at five years' age she would not have the same opportunities as boys, and later as an adult oscillating between engaging with women's organizations and hanging out with male friends. The theme of searching and longing for a community is similarly discussed by Tucker (2004), who suggests that because women-in-jazz communities host individuals who might not have very much in common, musically or otherwise, we should abandon nostalgia for unity and instead strive for "group identity with room for difference" (265).

\section{Challenging musical conventions}

The desire to focus on music is repeatedly voiced in our data, and music making is valued as a form of collective action different from talking. In the documentary, a Swedish saxophonist says music takes things to another level: "We can stand around chatting, but we can also play together and then something else happens" (dir. Norrmo 2015: 02.33-02.37). The project's attempt is to keep a double focus on music and verbal discussion, and while this is generally described as a welcome initiative, some still consider the focus on women and gender to overshadow the music.

As mentioned, a broad ambition with the project was to contribute to the growth of jazz as an art form. Two main targets for renewal are stressed in our data: musical conventions and audiences. Jazz music's reputation as difficult is attributed to a macho culture unattractive to younger audiences but hope for change through challenged musical conventions is also voiced. A senior Swedish vocalist says during a panel at the Swedish festival: "It seems younger women today increasingly choose freer forms of jazz rather than the traditional, where they have the chance to express themselves in more personal ways. No one can say: you played that 
wrong". The musicians in the Swedish sextet (all but one in their twenties or thirties) state preference to experimenting with musical arrangements, free-form improvisation and unconventional ways of using their instruments. In the documentary (dir. Norrmo 2015), they underline the need of having fun, being nerdy and composing happy music, thereby challenging jazz as conventionally serious, bringing to mind Smith's (2004) discussion of the Feminist Improvising Group (FIG). The musicians in the US quintet most of all emphasize experimenting with sound through instrumental set-ups, as described in the documentary. Their band leader points out that "a lot of women end up playing alternative instruments, you know there's a lot of harp and cello and string instruments not broadly seen in the jazz communities" (dir. Norrmo 2015: 19.00-19.12). In an interview, a Swedish industry representative (2017) argues that women, especially those musically welleducated, often find themselves in-between genres, which means they will not be booked by older, more traditional jazz clubs. In another interview, one of the Swedish project leaders (2016) similarly argues that a reason why many potential participants initially hesitated to register to the conference might be that "jazz musician" did not appear as a primary or self-evident identity. These statements foreground issues of instrument, genre and authenticity, and that women are associated with transgressive approaches not always welcomed by the industry. It is here worth keeping in mind that women's learning trajectories in jazz often appear to involve being tracked (by teachers and others) into traditional, less adventuresome musical practices (McKeage 2014[2002]; Tucker 2004).

In terms of audiences - the other target for renewal - one of the Swedish project leaders says in an interview (2016): "I believe the more women onstage, the more women in the audience". Her US collaborator, who is founder/director of the US festival, argues in the documentary that women musicians can offer something to jazz club owners, namely a way to attract a younger and more diverse audience who craves a broader variety on stage (dir. Norrmo 2015). Although these two statements might at first sight appear very similar, they are built on different arguments: the former is based on representation and statistical progress, the latter on marketability.

\section{Professional identification}

As mentioned above, our data shows that musicians voice a desire to be noted first and foremost as musicians. Besides wanting attention for one's individual musical competence, rather than one's designated sex (cf. Björck 2011), the desire to be seen as musician also relates to a strong collective identity and loyalty to the profession. This is articulated throughout our data and is especially prominent during a panel discussion about survival strategies in the industry at the Swedish festival. The panellists in this session display resistance towards describing their experiences as particular to women; they argue they would rather talk about the marginalized positions and difficult working conditions in jazz more generally. Members of the audience engage by pointing out freelance musicians' difficult economic conditions as highly relevant to gender-equality discussions, and some panellists agree, describing how they (for example) have had to turn down job offers because of taking care of small children. Freelance musicians' working conditions are thus variously seen as uniting all musicians, or as dividing women and men by being more difficult for mothers, especially single ones.

At the festival, some Swedish musicians stress that they identify themselves as musicians rather than female musicians - a claim which resonates with Tucker's (2004: 252) observation that the statement "I don't think of myself as a woman, I 
think of myself as a jazz musician" is a very common one among US women jazz musicians, both of the past and the present. During the panel mentioned above, some Swedish musicians in their forties and fifties argue that music in itself is gender-equal: a saxophonist describes music as integrative, being "the only language everyone in the whole world understands", and a percussionist finds it difficult to talk about music and equality since "music is a language which speaks to us in ways different than verbal communication". Portraying music as a universal and thereby gender-neutral language may provide a strategy for avoiding the obstacles and the exclusion many women encounter in jazz. However, by emphasizing similarity, such universalist discourses render power orders invisible, and may thereby contribute to reproducing them (cf. Bergman et al. 2016).

\section{Non-binary and intersectional critique}

Some individuals in the project, especially younger musicians in the Swedish context, criticize the 'women' label for excluding those with non-binary identities. Like the other themes we have discussed, this point of critique opposes generalizations of men and women as groups but goes further by entirely questioning a female-male binary, and thereby 'women' as a valid category. The argument was raised with great passion by a few younger musicians at the centre of the project. During a panel discussion at the Swedish festival, a saxophonist in the audience stands up to ask: "We use the words man and woman as if everyone knows what they mean, but I still don't know, what is a woman?". After some awkward silence in the room, generated by this question, a short discussion ensues on how binary gender categories are still needed in some contexts in order to be able to talk about inequalities and to perform measures. In the documentary (dir. Norrmo 2015), the same musician says: "I am not comfortable in my role as a woman at all, neither in my musical nor my personal life" (00.30-00.37), and later on: "When we talk about gender I think we should ask those who have more experience of living in conflict with gender norms, like transgendered people. We miss out on a lot of knowledge by only looking at men and women" (17.10-17.34). Later in interviews, the project leaders admit that the critique against a female-male binary caused them weariness, as the project under study was designed to counter gendered injustices as indicated by statistics based on these categories (Swedish project leader 2015a, Swedish project leader 2016). In conversations during fieldwork, the young Swedish musicians furthermore argue that the 'women' label over-simplifies issues of equality, rendering invisible other forms of discrimination at work in the industry. They call for socioeconomic background, ethnicity, age, functionality and sexuality to be taken into account, in order to consider who has access or not to culture projects and arts education.

\section{Other forms of resistance}

According to our analysis, the resistance described above against the 'women' label was mainly voiced by Swedish participants. From what we observed, for US participants other concerns seemed to be closer at hand. One such concern raised by American musicians was a need to reclaim and revalue feminine qualities and presentation. During a panel at the project's official kick-off, a US vocalist and composer argues that we should "let girls be girls", and that feminine attire such as high heels should not entail a devaluation of musical competence. The anger produced by being marginalized and degraded as too feminine, or feminine at all, is also described as a driving force. In the documentary, a US pianist and 
bandleader describes how she, after being criticized by a teacher for composing girly music, decided to not be discouraged and used the word girly in the name of her song (dir. Norrmo 2015). This form of resistance is not directed towards the project, but rather towards sexist jazz culture. The US project coordinator argues in an email interview (2017) that "If you are not male presenting, you are not given the same opportunity and freedom to perform, because you do not fit the standard, consumable, highly marketed and branded framework of who a jazz musician is 'supposed' to be". Again, we can see how marketability is emphasized as regulating women's participation in a US context.

Finally, a point of resistance raised at the Swedish festival by a few male industry representatives concerns possible detrimental effects on artistic quality. During a seminar, a middle-aged organizer stands up to ask how many people actually exist "on each side" (referring to the gender ratio among jazz musicians), arguing that some women had been given too frequent opportunities to perform at a local jazz club while other, more well-known, (male) bands had not been programmed. Thus, while the assumption that women's greater visibility on stage contributes to the growth of jazz as an art form is generally agreed upon in the project, it is not shared by everyone. To provide context for the organizer's comment: the Swedish national Arts Council had earlier the same year decided to make a small cut-down on its financial support to the Swedish Jazz Association, Svensk Jazz, as they had not reached the goal to include at least $25 \%$ women among artists featured at local jazz club stages. The decision was followed by hostile debates in the jazz field. In a panel discussion at the Swedish festival, the Arts Council's director-general says the cut-down generated an "unusual amount of aggressive responses" (see also de Boise 2017). A representative from the Swedish Jazz Association then commented that increasing the number of women on stage could be seen as a way of "scoring cultural policy points" and that while some measures produce nice-looking statistics, other measures go largely unnoticed. Another industry representative we interviewed (2017) says that some organizers find strategies for such scoring: "If for example a women's choir performs on stage, that club will get a gold star in terms of numbers, no need to book any more women that year". These comments raise questions about what statistics do. Do they provide an effective indicator of whether gender equality is achieved? And, when authority institutions (such as the Arts Council) regulate organizations' equality work by rewarding numerical progress, may some inequalities thereby be overlooked?

\section{Conclusion: Discourses of unity and diversity}

In this article, we have examined points of resistance voiced in response to a project designed to encourage, support and make visible women musicians and composers in jazz; to further discussions and knowledge about how to achieve a gender equal jazz scene; and to thereby contribute to the growth of jazz as an art form. We wish to stress that the project also received a lot of positive response and appeared as deeply appreciated by many participants. However, our focus on more resistive responses found these to centrally concern the use of the label 'women', variously claiming that the label confirms binary gender difference instead of promoting gender equality, assumes a sisterhood solidarity which cannot be taken for granted, draws attention away from music, excludes non-binary identities, and overshadows other power hierarchies at work in the industry. A less dominant point of resistance, voiced by a few organizers, was centred around the argument that gender equality policy invites a form of point-scoring which might counteract quality. 
The resistance against the 'women' label was, from what we observed, voiced primarily by Swedish jazz musicians. This does not mean that US musicians generally do not hold such views, in the present project or elsewhere (see Tucker 2004). Perhaps such arguments were voiced, but outside public debate. It might be that Sweden, through its institutionalized tradition for gender equality work and better opportunities for musicians to obtain public grants, provides a platform where resistance can be played out in ways different from the US, where musicians appear to be subjected to greater pressure to be marketable. More data from the US festival activities would perhaps enable a more multi-faceted analysis of discourses voiced by musicians and other actors in the US.

Besides varying between Sweden and the US, this resistance also varied by generation. Even though the resistance against the 'women' label formed a common ground, gender equality discourses invoked either unity or diversity. While a discourse of unity - claiming that jazz musicians are united by the universal language of music, by difficult economic conditions and by their professional identity as freelancers - was more commonly used by musicians in their forties or older, musicians in their twenties and thirties more often made use of a discourse of diversity, emphasizing the importance of creating a space for plural gender identities - including queer, trans and non-binary - but also in regards to other hierarchies such as sexuality, ethnicity, age, and functionality. Intersectionality has been described as a key issue for contemporary, fourth wave feminists (Munro 2013), and women-centred music initiatives operated by younger generations in Sweden generally seem to embrace diversity issues. While the women's movement in the US, with its diverse population and its high level of political mobilization, faced discussions on racial and sexual diversity decades ago, such discussions seem to be more recently actualized in Sweden, not just in subcultural contexts but on a highly institutionalized arena and in public debate.

Visibility is a central feature in Western contemporary culture. Women's visibility has been highlighted as a central ambition for gender equality efforts generally, and especially in relation to young women in popular music (Björck 2011 , 2013). However, by using the concept of gaze, we can see that being looked at means being seen as something, and this something refers to discursive categories which might be both uncomfortable and unwanted. In other words, visibility entails a form of representational work, in which head counting, marketing and promotion all constitute different aspects of representing women. The resistance voiced in our data calls for problematization of such representation and the assumptions conveyed through gender equality efforts, including the very words we use to address people and to name projects. We should also remember that being seen is not necessarily the same as feeling supported or encouraged.

Our results have demonstrated some of the complexity of a discursive field where meanings of gender equality work in jazz are elaborated and contested. In this field, individuals must navigate between discourses on jazz music, masculinity, femininity, gender equality and individual musicianship, along with market and organizational control, and intersectional claims that other power orders are to be taken into account. The resistance we have analyzed is voiced within a particular women-in-jazz project but relates to jazz culture more broadly and has been placed here within this debate. Our results therefore say something about power relations in the wider field of jazz. We hope to inspire and challenge other researchers to continue this exploration, as there is much still to do. 


\section{Endnotes}

1 This tradition has created an image of Sweden as one of the most gender equal countries, an image which however has recently been problematized by Martinsson et al. (2016).

2 As noted by Mazur et al. (2016: 669), "women's movement ideas can vary within the general guidelines of gendered, woman-focused discourse", and "any particular women's movement actor could use feminist discourse in some situations and non-feminist discourse in other situations".

3 The documentary (which is mostly in Swedish) is not a commercial product and is not available for sale online, but rather serves as an internal product for project documentation.

\section{Acknowledgements}

The study from which this article draws its data was made possible by a planning grant by the Centre for Interdisciplinary Gender Research (GIG) at the University of Gothenburg. The authors also wish to thank the Swedish Jazz Association and International Women in Jazz for providing background information.

\section{References}

\section{Bibliography}

Alcoff, L. 1988. Cultural Feminism versus Post-Structuralism: The Identity Crisis in Feminist Theory. Signs 13 (3): 405-436. http://www.jstor.org/stable/3174166 Accessed: 5 December 2017.

Annfelt, T. 2003. Jazz as Masculine Space. Kilden [Online]. http://kjonnsforskning.no/en/2003/07/jazz-masculine-space Accessed: 28 November 2017.

Bayton, M. 1998. Frock rock: Women performing Popular Music. Oxford: Oxford University Press.

Bergman, Å. et al. 2016. Struggling for Integration: Universalist and Separatist Discourses within El Sistema Sweden. Music Education Research 18 (4): 364375. http://dx.doi.org/10.1080/14613808.2016.1240765

Björck, C. -

2011. Claiming space: Discourses on Gender, Popular Music, and Social Change. PhD. University of Gothenburg, Gothenburg. http://hdl.handle.net/2077/24290 Accessed: 27 December 2017.

2013. A Music Room of One's Own: Discursive Constructions of Girls-Only Spaces for Learning Popular Music. Girlhood Studies 6 (2): 11-29. http://dx.doi.org/10.3167/ghs.2013.060203

Brah, A. and Phoenix, A. 2004. Ain't I a Woman? Revisiting Intersectionality. Journal of International Women's Studies 5 (3): 75-86. http://vc.bridgew.edu/jiws/vol5/iss3/8 Accessed: 27 December 2017.

Brewer, C. G. 2017. Changing the Tune: The Kansas City Women's Jazz Festival, 1978-1985. Denton, TX: University of North Texas Press.

Caudwell, J. 2012. Jazzwomen: Music, Sound, Gender and Sexuality. Annals of Leisure Research 15 (4): 389-403. http://dx.doi.org/10.1080/11745398.2012.744275

Citron, M. J. 2000[1993]. Gender and the musical Canon. ([New ed.]). Urbana: Univ. of Illinois Press. 
Coates, N. 1997. (R)evolution Now? Rock and the political Potential of Gender. In S. Whiteley Ed. Sexing the Groove: Popular Music and Gender. London: Routledge: 50-64.

de Boise, S. 2017. Tackling Gender Inequalities in Music: A comparative Study of Policy Responses in the UK and Sweden. The International Journal of Cultural Policy. http://dx.doi.org/10.1080/10286632.2017.1341497

Denson, L. 2014. Perspectives on the Melbourne International Women's Jazz Festival. Jazz Research Journal 8 (1-2): 163-181. http://dx.doi.org/10.1558/jazz.v8i1-2.26774

Dougher, S. and Keenan, E. K. 2012. Riot Grrrl, Ladyfest and Rock Camps for Girls. In J. Downes Ed. Women make Noise: Girl Bands from Motown to the Modern. Twickenham: Supernova: 259-291.

Foucault, M. 1972. The Archaeology of Knowledge. London: Routledge.

1977. Discipline and punish: The birth of the prison. London: Allen Lane. 1982. The Subject and Power. Critical Inquiry 8 (4): 777-795.

http://www.jstor.org/stable/1343197 Accessed: 27 December 2017

Ganetz, H. 1998. Her Voices: Mediated female Texts in a cultural Perspective. Nordicom Review 19 (1): 215-224.

http://www.nordicom.gu.se/en/tidskrifter/nordicom-review-11998/her-voicesmediated-female-texts-cultural-perspective Accessed: 27 December 2017.

Giffort, D. M. 2011. Show or Tell? Feminist Dilemmas and Implicit Feminism at Girls' Rock Camp. Gender and Society 25(5): 569-588. http://dx.doi.org/10.1177/0891243211415978

Gooley, D. 2011. The Outside of "Sitting In": Jazz Jam Sessions and the Politics of Participation. Performance Research 16(3). pp 43-48. http://dx.doi.org/10.1080/13528165.2011.606024

Green, L. 1997. Music, Gender, Education. Cambridge: Cambridge Univ. Press.

Hammersley, M. and P. Atkinson. 2006[1995]. Ethnography. Principles in Practice. London: Routledge.

Heble, A. and Siddall, G. 2000. Nice Work if you can get it: Women in Jazz. In A. Heble Ed. Landing on the wrong Note. Jazz, Dissonance and critical Practice New York/London: Routledge: 141-166.

Istvandity, L. 2016. Sophisticated Lady: Female Vocalists and Gendered Identity in the Brisbane Jazz Scene. Journal of World Popular Music 3 (1): 75-89. http://dx.doi.org/10.1558/jwpm.v3i1.31197

Keenan, E. K. 2008. "Who are you calling 'Lady'?": Femininity, Sexuality, and Third-Wave Feminism. Journal of Popular Music Studies 20 (4): 378-401. http://dx.doi.org/10.1111/j.1533-1598.2008.00170.x

Kernodle, T. L. 2014. Black Women working together: Jazz, Gender, and the Politics of Validation. Black Music Research Journal 34 (1): 27-55. http://dx.doi.org/10.5406/blacmusiresej.34.1.0027

Leonard, M. 2007. Gender in the Music Industry: Rock, Discourse and Girl Power. Aldershot, England: Ashgate.

Martinsson, L. et al Eds. 2016. Challenging the Myth of Gender Equality in Sweden. Bristol: Policy Press.

Mazur, A. G. et al. 2016. Comparative Strength of Women's Movements over Time: Conceptual, empirical, and theoretical Innovations. Politics, Groups, and Identities 4 (4): 652-676. https://doi.org/10.1080/21565503.2015.1102153

McKeage, K. 2014[2002]. "Where are all the Girls?" Women In collegiate instrumental Jazz. GEMS (Gender, Education, Music, \& Society) 7 (3): 12-19. 
https://ojs.library.queensu.ca/index.php/gems/article/view/5207 Accessed: 27 December 2017.

Monson, I. 1995. The Problem with White Hipness: Race, Gender, and Cultural Conceptions in Jazz Historical Discourse. Journal of the American Musicological Society 48 (3): 396-422. https://doi.org/10.2307/3519833

Munro, E. 2013. Feminism: A Fourth Wave? Political Insight 4 (2): 22-25. https://doi.org/10.1111/2041-9066.12021

Pellegrinelli, L. 2008. Separated at "Birth": Singing and the History of Jazz. In N. T. Rustin and S. Tucker Eds. Big Ears: Listening for Gender in Jazz Studies. Durham/London: Duke University Press: 31-47.

Scott, J. 1988. Deconstructing Equality-versus-Difference: Or, the Uses of PostStructuralist Theory for Feminism. Feminist Studies 14 (1): 33-50. http://www.jstor.org/stable/3177997 Accessed: 27 December 2017.

Statens kulturråd. 2009. På Väg mot jämstä lld Scenkonst [On the Road to Gender-Equal Performing Arts], Kulturrådets skriftserie 2009:1. Stockholm: Statens kulturråd [Swedish Arts Council]. http://www.kulturradet.se/Documents/publikationer/2009/pa vag mot jamstall d.pdf. Accessed: 1 December 2017.

Smith, J. D. 2004. Playing Like a Girl: The Queer Laughter of the Feminist Improvising Group. In D. Fischlin, and A. Heble Eds. The Other Side of Nowhere: Jazz, Improvisation and Communities in Dialogue. Connecticut: Wesleyan University Press: 224-43.

Suzuki, Y. 2013. Two Strikes and the Double Negative: The Intersections of Gender and Race in the Cases of Female Jazz Saxophonists. Black Music Research Journa/ 33 (2): 207-226. http://dx.doi.org/10.5406/blacmusiresej.33.2.0207

Sweden. Kommittén för jämställdhet inom scenkonstområdet [Committee for Gender Equality in the Performing Arts]. 2006. Plats på scen. Betänkande [On stage. Report]. Stockholm: Fritze.

http://www.regeringen.se/rattsdokument/statens-offentligautredningar/2006/04/sou-200642/ Accessed: 27 December 2017.

Tucker, S. -

2004. Bordering on Community: Improvising Women Improvising Women-inJazz. In D. Fischlin and A. Heble Eds. The Other Side of Nowhere: Jazz, Improvisation and Communities in Dialogue. Connecticut: Wesleyan University Press: 244-267.

2016. Jazz History Remix: Black Women from "Enter" to "Center". In P. K. Maultsby and M. V. Burnim Eds. Issues in African American Music: Power, Gender, Race, Representation. New York: Routledge: 256-269.

Wehr, E. L. 2016. Understanding the Experiences of Women in Jazz: A suggested Model. International Journal of Music Education 34 (4): 472-487. http://dx.doi.org/10.1177/0255761415619392

Young, I. M. 1989. Throwing like a Girl: A Phenomenology of feminine Body Comportment, Motility, and Spatiality. In J. Allen and I. M. Young Eds. The thinking Muse: Feminism and Modern French philosophy. Bloomington: Indiana University Press: 51-70.

\section{Videography}

noteringar normer: Women in Jazz 2015, 2015. Dir. Neta Norrmo. DVD. Kultur i Väst. 


\section{Interviews}

Swedish project leader \#1. 2015a. Interviewed by author, 15 October.

Swedish project leader \#1. 2015b. Interviewed by author, 16 November.

Swedish project leader \#2. 2016. Interviewed by author, 30 March.

US project coordinator. 2017. Interviewed by author over email, 4 December.

Swedish industry representative. 2017. Interviewed by author over telephone, 17

December.

US festival founder/director. 2017. Interviewed by author over email, 22

December. 